\title{
A LOAN WORD IN THE NOBEL QUR'AN
}

\author{
Andri Purwanto \\ Program of English Education, Faculty of Language and Art, University of Indraprasta PGRI \\ Jalan Nangka No. 58C Tanjung Barat, Jagakarsa, South Jakarta 12530 \\ purwanto.andri.unindra@gmail.com
}

\begin{abstract}
The objective of this research is to analyze the Islamic terms according to translation theories. One of the translation theories is modifying a loan word with meaning components, i.e., form, additions, couplets, synonym, comparison, and a classifier. This theory is introduced by Larson in dealing with cultural and biblical terms. This research is a library research and the source data is taken from the Noble Qur'an, English translation and commentary translated by Dr Muhammad Taqi-ud-Din Al-Hilali dan Dr Muhammad Muhsin Khan. The research discusses some translation theories, i.e., 1) a loan with features of form, 2) a loan word with function, 3) a loan word with form and function, 4) a loan word with a comparison, 5) a loan word with a classifier, 6) a loan word with couplets, triplets, quadruplets and quintaplets, 7) a loan word with a synonym, 8) a loan word with a a synonym plus reference, and 9) a loan word with no modification.
\end{abstract}

Key words: translation theories, loan word, the Noble Qur'an

\begin{abstract}
ABSTRAK
Tujuan dari penelitian ini adalah untuk menganalisis istilah-istilah agama Islam sesuai dengan teori penerjemahan. Penelitian ini merupakan penelitian kepustakaan yang datanya diambil dari al-Qur'an terjemahan berbahasa Inggris yang diterjemahkan oleh Dr Muhammad Taqi-ud-Din Al-Hilali dan Dr Muhammad Muhsin Khan. Penelitian ini membahas beberapa teori penerjemahan: (1) a loan with features of form, (2) a loan word with function, (3) a loan word with form and function, (4) a loan word with a comparison, (5) a loan word with a classifier, (6) a loan word with couplets, triplets, quadruplets and quintaplets, (7) a loan word with a synonim, and (8) a loan word with a a synonim plus reference, (9) a loan word with no modification.
\end{abstract}

Kata kunci: teori penejermahan, kata pinjaman, al-Qur'an 


\section{INTRODUCTION}

Translation of Islamic Terms using a generic word is one of the translation strategies that is used to visualize the Islamic terms when there is no equivalence word in the target language. This strategy of translation helps the non-Arabic-speaking Muslims to understand the Islamic terms more detail with some additions. This effort is made in fulfillment of the injunction of the Prophet peace be upon him, "Convey my message even if it be one single ayah." The idea of translating Islamic terms in the Qur'an is not an easy task since the Islamic terms in the qur'an sometimes have no English equivalent. Based on this reason, the study of translating Islamic terms with a generic word and a descriptive phrase is badly needed.

Those who are going to translate Islamic terms should learn the Qur'an acording to the understanding of the pious pedecessors, the Companions of Alloh's Messenger. Why we need to understand the Qur'an based on the Compnaions of Alloh's Messenger because They learnt the Qur'an directly from the Prophet peace be upon him. The Alloh's Messenger clarify the word "Zulm" when it was recited for the first time to all of the Companions of Alloh's Messenger. Most of the Companions had misunderstood the meaning of the word "Zulm" in the Surah 6. Al-An'am: 82, and they ask an explanation from the Prohpet peace be upon him. Narrated 'Abdullah رضى اله عن: When the following Verse was revealed: "It is those who believe (in the Oneness of Alloh and worship none but Him Alone) and confuse not their belief with Zulm (wrong i.e., by worshipping others besides Alloh.) ..." (V.6:82), the صلى Companions of Alloh's Messenger said, "Who is amongst us who had not done Zulm (wrong)?" Then
Alloh j revealed: "Verily, joinning others in worship with Alloh is a great Zulm (wrong) indeed." (V.31:13) (Sahih Al-Bukhari, Vol. 1 Hadith No.31). The translation of the word "Zulm" is using a generic word (wrong) with a descriptive phrase (by worshipping others besides Alloh). Larson (1984:158) had mentioned that "If necessary, the generic word may be modified with a descriptive phrase to add any contrastive components which are needed for a clear understanding of the source lexical item."

The reality today is that some translators translate the Islamic terms in the Qur'an by word-by-word translation (Lafziyah) and unduly free translations (free interpretation). According to Larson (1984:17):

"Unduly free translations are not considered acceptable translation for most purposes. Translations are unduly free if they add extraneous information not in the source text, if they change the meaning of the source language, or if they distort the facts of the historical and cultural setting of the source language text. Sometimes unduly free translations are made for purposes of humor, or to bring about a special response from the receptor language speakers. However, they are not acceptable as normal translations. The emphasis is on the reaction of those reading or hearing it and the meaning is not necessarily the same as that of the source language."

In Indonesia, there are so many translations of the Qur'an translated word-by-word in order to know the meaning of each Arabic word. This method of translation may distort the meaning of the Qur'an and mischieve most people who read this word-by- 
word Qur'anic translation. The Islamic scholars and professional translators have agreed that there is no word-byword translation, and this is unlawful (Haram) if it is applied to the translation of the Qur'an. And those who know nothing about the Qur'an and its meaning but are trying to get the meaning done from other sources (i.e. philosophy books, dictionaries, people's comments), this wrongful action may distort them from the right path (the Qur'an and the Sunnah). And what Alloh has mentioned: "But whosoever turns away from My reminder (i.e. neither believes this Qur'an nor acts its teachings). Verily, for him is a life of hardship and We shall raise him up blind on the Day of Resurrection (Surah 20. Taha:124).

The most important thing is to find a trustable translator. The translation of Bible from Jewish language, Hebrew into Latin, the Ancient Rome language. The Bible that was written in Hebrew language was translated by the Greece scholar into the Greek language. The Ancient Greek people believed in many gods at that time so they translated the Bible according to their belief. Since then the Greek language became the most important language in the history of Europe. The New Testament of the Christian Bible was written in Greek language. The Roman people translated the Greek Bible into the Latin language easily. This is the second reproduction of translation that is totally difference to the original text. That's why there are a lot of disputation in the translated script of the Bible.

Translation of the Islamic terms in the Qur'an is badly needed to disseminate the scientific procedures of translation of the Holy Qur'an to all Muslim. I hope that treatise serves as a source of benefit for all Muslim and that it is a cause for them to be guided to the truth and to the way of worshipping Alloh correctly. May Alloh place this noble work on the scale of good deeds.

This research discusses some problems and strategies of translation, that is, the analysis of strategies that the professional translators employ in the English translation of Noble Qur'an and the percentage of each strategy that the professional translators employed in dealing with Islamic terms in the Noble Qur'an.

Translation happened at the first time during the third century $\mathrm{BC}$. The previous name of translation was known as Septuagint. There are 72 Jewish scholars who were involved in the translation of Bible from Hebrew into Greek. The translation of Bible into Greek was the beginning of many translations of Bible into many other languages, especially Latin. Eugene Nida (1959-1998:12-23) places the beginning of translation with the production of the Septuagint which seems to have been the first translation of the Hebrew Old Testament into Greek. It was carried out by seventytwo translators, and it provides us with the basic categories of the history of this practice.

The Latin Biblical texts had accumulated piecemeal over a century or more, they were not translated by a single person or institution, nor uniformly edited. The individual books varied in quality of translation and style, and different manuscripts witness variations in readings. The Old Testament Books of Old Latin was translated from Greek Biblical text, not from the Hebrew. The translation of Hebrew Biblical text into Greek Biblical texts was involved 72 Jewish Scholars with different interpretations each. Then, the Roman people translated the Greek Biblical text into 
Latin not only individually but also collectively and never be uniformedly edited. The result is there so many different translations and styles of the printed books of Latin Biblical text.

That is a brief history of translation in the ancient time and some problems arised during the long process of translation. There are so many translation problems, i.e. untrusted translators, wrong translation methods, such as word-by-word translation, different interpretations, non-original text translation and adaptation that forced the meaning change to suit different conditions. Based on the historical problems of translation, the definition of translation can be concluded as a process of translating the meaning of the source language text into the target language text by studying the meaning according to the four elements of translation, i.e. lexicon, grammatical structure, communication situation, cultural context and restructuring the translated text into an equivalent, accurate, dynamic and natural translation.

What is the best translation? Larson (1998:6) explained that the best translation is one which a) uses the normal language forms of the receptor language, b) communicates, as much as possible, to the receptor language speakers the same meaning that was understood by the speakers of the source language, and c) maintains the dynamics of the source language text. Every translation should have these three, so the readers of the receptor language will not see the translation as a translated text.

The use of loan word as a term that the readers should know is badly needed. This kind of translation method is retained to spread the Islamic terms towards Muslim people. For example,

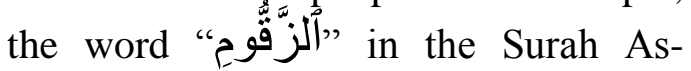

Saffat Verse 62 is translated into "the tree of Zaqqum" and modified with features of form (a horrible tree in Hell). This meaning has three meaning components, the first is THING (tree), the second is ATTRIBUTE (horrible), and the third is RELATION (in Hell).

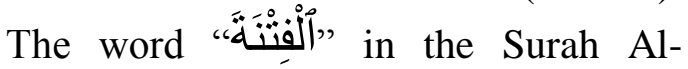
Ahzab Verse 14 is translated into a loan word "Al-Fitnah" is modified with function (to renegade from Islam to polytheism). This meaning has two meaning components, the first is EVENT (to renegade from Islam) and the second is RELATION (to

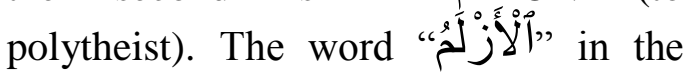
Surah Al-Maidah Verse 90 is translated into a loan word "Azlam" and modified with a features of form "arrows" and function "for seeking luck or decision." This meaning has two meaning components, the first is THING (arrows) and the second is FUNCTION (for seeking luck or decision). This meaning has two meaning components, the first is THING "arrows" and the second is EVENT "for seeking luck or decision." The word "الَْاعَاعَونَ" in the Surah Al-Ma'un Verse 7 is translated into a loan word "Al-Ma'un" and modified with a comparison "small kindnesses like salt, sugar, water." The meaning has two meaning components, the first is THING "smal kindnesses" and RELATION "like salt, sugar, water."

The word "كَافُورَ" in the Surah Al-Insan Verse 5 is translated into a loan word "Kafur" and modified with a classifier "water from a spring in Paradise called." This meaning has three meaning components, the first is THING "water", the RELATION "from a spring in Paradise", and the third is

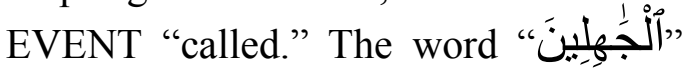
in the Surah Al-Baqarah Verse 67 is translated into a loan word "Al-Jahilun" 
and a couplet "the ignorant or the foolish." This meaning has one meaning component that is a THING "the foolish or the ignorant." The word "غَيْبَ" in the Surah Al-Baqarah Verse 33 is translated into a loan word "Ghaib" and modified with a synonym "Unseen." The word "لَحْسنْنَ' in the Surah Al-Lail Verse 9 is translated into a loan word "Al-Husna" and modified with a reference "See the footnote of the Verse No. 6." The word "أرضّكعين" in the Surah Al-Baqarah Verse 43 is translated into a loan word "Ar-Rakiun" with no modification.

\section{METHOD}

This research discusses the analysis of the loan words in The Noble Qur'an English Translation of the Meanings and Commentary translated by Dr. Muhammad Taqi-ud-Din AlHilalli dan Dr. Muhammad Muhsin Khan and published by King Fahd Complex for the Printing of Holy Qur'an, Madinah, K.S.A. This research is derived from the Noble Qur'an English Translation of the meanings and commentary written by Dr Muhammad Taqi-ud-Din Al-Hilalli and Dr Muhammad Muhsin Khan. This research used a library research method to design the theory and strategy of translation and the whole data were presented in number and persentage.
This research analyzed the data based on the theory and strategy of translation.

\section{RESULTS AND DISCUSSION}

In translating Islamic terms, the translators employed some translation techniques: (1) a loan word with form; (2) a loan word with function; (3) a loan word with both form and function; (4) a loan word with a comparison; (5) a loan word with a classifier; (6) a loan word with couplets, triplets, quadruplets and quintuplets; (7) a loan word with a synonym; (8) a loan word with a synonym plus reference; (9) a loan word with no modification. There are nine types of loan word with its modification. The analysis of the translation theories is based on some translation theories. Some quotations will be inserted to support the analysis.

\section{A Loan Word with Features of Form}

In the translation of Islamic terms, loan words that contribute to the nearest meaning of generic terms are badly needed. Many translators use different ways in translating Islamic terms that probably need to be translated concretely based on the Qur'an and AsSunnah to avoid misunderstanding. Larson (1998:165) mentioned that "Understanding correspondence of form and function is crucial to finding good lexical equivalents."

Data Number 1

\begin{tabular}{|c|c|c|}
\hline No. & Arabic & English \\
\hline 1. & 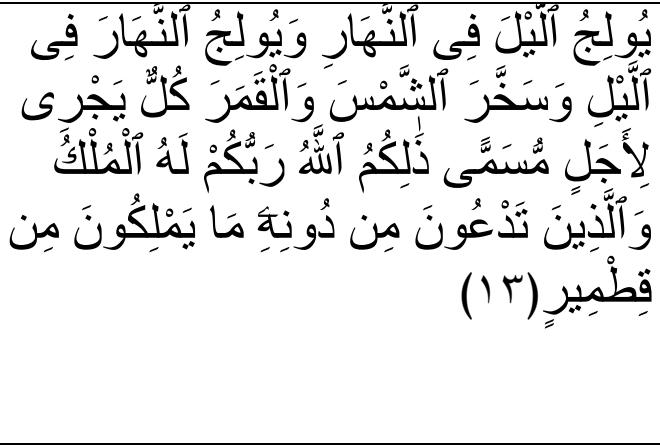 & $\begin{array}{l}\text { He merges the night into the day (i.e. the } \\
\text { decrease in the hours of the night is added } \\
\text { to the hours of the day), and He merges } \\
\text { the day into the night (i.e. the decrease in } \\
\text { the hours of the day is added to the hours } \\
\text { of the night). And He has subjected the } \\
\text { sun and the moon: each runs its course for } \\
\text { a term appointed. Such is Allah, your } \\
\text { Lord; His is the kingdom. And those, } \\
\text { whom you invoke or call upon instead of }\end{array}$ \\
\hline
\end{tabular}




\begin{tabular}{|l|l|}
\hline & $\begin{array}{l}\text { Him, own not even a Qitmir (the thin } \\
\text { membrane over the date-stone). [Verse } \\
35: 13, \text { page 583] }\end{array}$ \\
\hline
\end{tabular}

Analysis:

The word "Qitmir" has three meaning components (ATTRIBUTE, THING and RELATION). The word "thin" belongs to ATTIBUTE; the word "membrane" belongs to THING; and the phrase "over the date-stone" belongs to RELATION. The loan word "Qitmir" is modified with features of form which has three meaning components. To do that he must have also studied the skewing of the receptor language grammar in relation to the semantic structure and know how to use this skewing to reconstruct meaning in a natural way in the receptor language, said Larson (1998:31).

Data Number 4

\begin{tabular}{|c|c|c|}
\hline No. & Arabic & English \\
\hline 4. & 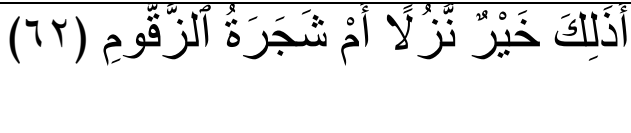 & $\begin{array}{l}\text { Is that (Paradise) better entertainment or } \\
\text { the tree of Zaqqum (a horrible tree in } \\
\text { Hell)? [Verse 37: 62, page 600] }\end{array}$ \\
\hline
\end{tabular}

Analysis:

The word "Zaqqum" is translated using a loan word (Zaqqum) with a classifier (the tree of) into "the tree of Zaqqum" and modified with features of form (a horrible tree in Hell). The word "Zaqqum" has three meaning components (ATTRIBUTE, THING and RELATION). The word "horrible" belongs to ATTIBUTE; the word "tree" belongs to THING; and the phrase "in Hell" belongs to RELATION. The loan word "Zaqqum" is modified with features of form which has three meaning components. To do that he must have also studied the skewing of the receptor language grammar in relation to the semantic structure and know how to use this skewing to reconstruct meaning in a natural way in the receptor language, said Larson (1998:31).

\section{A Loan Word with Function}

In the translation of Islamic terms, loan words that contribute to the nearest meaning of generic terms are badly needed. Many translators use different ways in translating Islamic terms that probably need to be translated concretely based on the Qur'an and AsSunnah to avoid misunderstanding. Larson (1998:165) mentioned that "Understanding correspondence of form and function is crucial to finding good lexical equivalents."

Data Number 1

\begin{tabular}{|c|c|c|}
\hline No. & Arabic & English \\
\hline 1. & 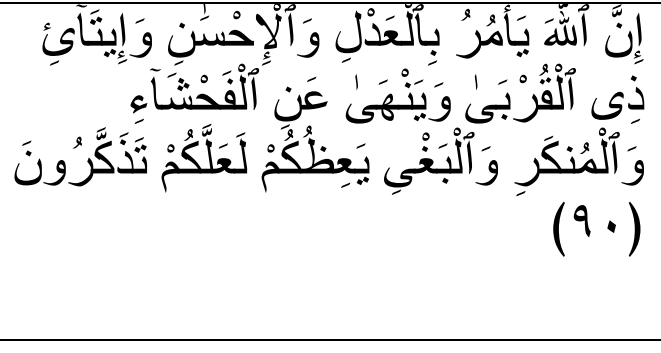 & $\begin{array}{l}\text { Verily, Allah enjoins Al-Adl (i.e. } \\
\text { justice and worshipping none but } \\
\text { Allah Alone -Islamic Monotheism) } \\
\text { and Al-Ihsan [i.e. to be patient in } \\
\text { performing your duties to Allah, } \\
\text { totally for Allah's sake and in } \\
\text { accordance with the Sunnah (legal }\end{array}$ \\
\hline
\end{tabular}






Analysis:

The word "Al-Ihsan" is modified with function (to be patient in performing your duties to Allah, totally for Allah's sake and in accordance with the Sunnah (legal ways) of the Prophet صلى الله عليه وسلم in a perfect manner). The word "Al-Ihsan" has one meaning component, that is EVENT. The phrasal verb (to be patient in performing your duties to Allah, totally for Allah's sake and in accordance with the Sunnah صلى الله عليه (legal ways) of the Prophet in a perfect manner) belongs to EVENT. To do that he must have also studied the skewing of the receptor language grammar in relation to the semantic structure and know how to use this skewing to reconstruct meaning in a natural way in the receptor language, said Larson (1998:31).

Data Number 2

\begin{tabular}{|c|c|c|}
\hline No. & Arabic & English \\
\hline 2. & 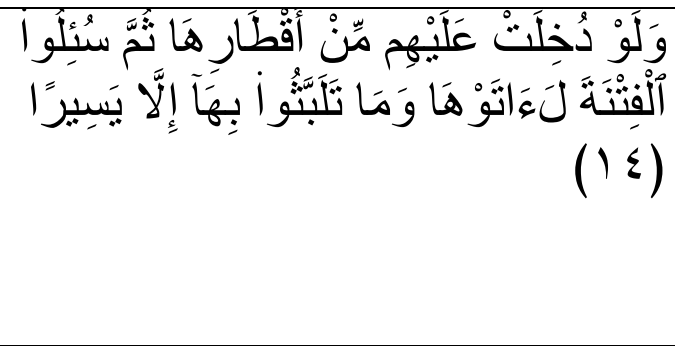 & $\begin{array}{l}\text { And if the enemy had entered from all } \\
\text { sides (of the city), and they had been } \\
\text { exhorted to Al-Fitnah (i.e. to } \\
\text { renegade from Islam to polytheism), } \\
\text { they would surely have committed it } \\
\text { and would have hesitated thereupon } \\
\text { but little. [Verse } 33: 14 \text {, page } 561 \text { ] }\end{array}$ \\
\hline
\end{tabular}

\section{Analysis:}

The word "Al-Fitnah" is modified with function (to renegade from Islam to polytheism).

\section{A Loan Word with both Form and Function}

In the translation of Islamic terms, loan words that contribute to the nearest meaning of generic terms are badly needed. Many translators use different ways in translating Islamic terms that probably need to be translated concretely based on the Qur'an and AsSunnah to avoid misunderstanding. Larson (1998:165) mentioned that "Understanding correspondence of form 
and function is crucial to finding good lexical equivalents."

Data Number 28

\begin{tabular}{|c|c|c|}
\hline No. & Arabic & English \\
\hline 28. & 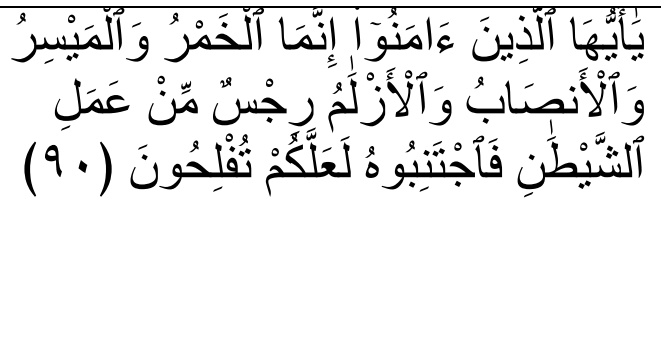 & $\begin{array}{l}\text { O you who believe! Intoxicants (all kinds } \\
\text { of alcoholic drinks), and gambling, and } \\
\text { Al-Ansab } \text { b }^{[3]} \text {, and Al-Azlam (arrows for } \\
\text { seeking luck or decision) are an } \\
\text { abomination of Shaitan's (Satan) } \\
\text { handiwork. So avoid (strictly all) that } \\
\text { (abomination) in order that you may be } \\
\left.\text { successful }^{[4]} \text {. [Verse 5: 90, page } 162\right]\end{array}$ \\
\hline
\end{tabular}

Analysis:

The word "Azlam" is modified with a form "arrows" and a function "for seeking luck or decision". This modification consists of THING (arrows) and RELATION (for seeking luck or decision). The loan word "Azlam" has two meaning components. Larson (1998:169) mentioned that the purpose of the modification should be to help this receptor language reader understand.

Data Number 4

\begin{tabular}{|c|c|c|}
\hline No. & ic & English \\
\hline 4. &  & $\begin{array}{l}\text { It is He who has sent down to you } \\
\text { (Muhammad صلى اله عليه وسلم) the Book } \\
\text { (this Qur'an). In it are Verses that are } \\
\text { entirely clear, they are the foundations of } \\
\text { the Book [and those are the Verses of Al- } \\
\text { Ahkam (commandments), Al-Fara'id } \\
\text { (obligatory duties) and Al-Hudud (legal } \\
\text { laws for the punishment of thieves, } \\
\text { adulterers)]; and others not entirely } \\
\text { clear. So as for those in whose hearts } \\
\text { there is a deviation (from the truth) they } \\
\text { follow that which is not entirely clear } \\
\text { thereof, seeking Al-Fitnah (polytheism } \\
\text { and trials), and seeking for its hidden } \\
\text { meanings, but none knows its hidden } \\
\text { meanings save [except] Allâh. And those } \\
\text { who are firmly grounded in knowledge } \\
\text { say: "We believe in it; the whole of it } \\
\text { (clear and unclear Verses) are from our } \\
\text { Lord." And none receive admonition } \\
\text { except men of understanding. (Tafsir At- } \\
\text { Tabari). [Verse } 3: 7 \text {, page 68] }\end{array}$ \\
\hline
\end{tabular}

Analysis:

The word "Hudud" is modified with a form "legal laws" and a function "for the punishment of the thieves, adulterers". This modification consists of THING (laws), ATTRIBUTE (legal) and RELATION (for the punishment of the thieves, adulterers). The loan word 
"Hudud" has three meaning components. Larson (1998:169) mentioned that the purpose of the modification should be to help this receptor language reader understand.

\section{A loan word with comparison}

In the translation of Islamic terms, loan words that contribute to the nearest meaning of Islamic terms are badly needed. Many translators use different ways in translating Islamic terms that probably need to be translated concretely based on the Qur'an and AsSunnah to avoid misunderstanding. Larson (1998:165) mentioned that "The form and function are no made explicit, but rather, a comparison is made to something which is already well known in the receptor language and for which there is a lexical item."

Data Number 2

\begin{tabular}{|c|c|c|}
\hline No. & Arabic & English \\
\hline 2. & وَيَمْنَعَونَ أَلْمَاعُونَ (V) & $\begin{array}{l}\text { And prevent } \boldsymbol{A l - M a} \text { 'un (small kindnesses } \\
\text { like salt, sugar, water). [Verse 107: } 7 \text {, } \\
\text { page } 852 \text { ] }\end{array}$ \\
\hline
\end{tabular}

Analysis:

The word "Al-Maun" is modified with form (small kindnesses) and a comparison (like salt, sugar, water). The modification consists of THING (kindnesses), ATTRIBUTE (small) and RELATION (like salt, sugar, water). The word "Al-Maun" has three meaning components, ATTRIBUTE, THING, and RELATION.

Data Number 4

\begin{tabular}{|c|c|c|}
\hline No. & Arabic & English \\
\hline 4. & 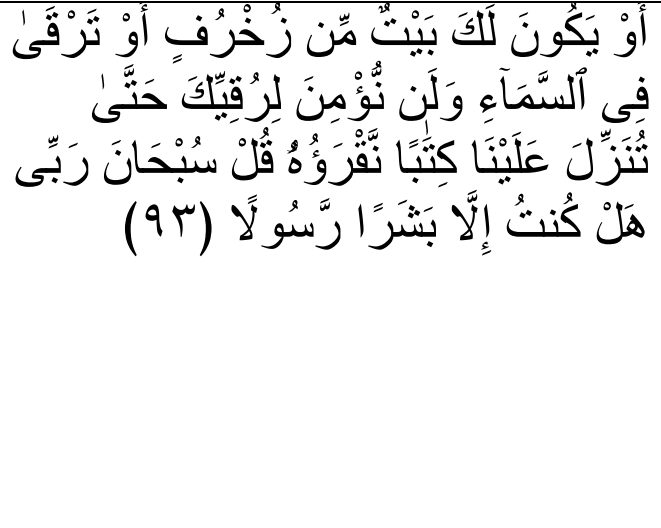 & $\begin{array}{l}\text { "Or you have a house of Zukhruf (like } \\
\text { silver and pure gold), or you ascend } \\
\text { up into the sky, and even then we will } \\
\text { put no faith in your ascension until } \\
\text { you bring down for us a Book that we } \\
\text { would read." Say (O Muhammad "لهاله عليه وسلم): "Glorified (and exalted) } \\
\text { be my Lord [(Allâh) above all that evil } \\
\text { they (polytheists) associate with Him]! } \\
\text { Am I anything but a man, sent as a } \\
\text { Messenger?" [Verse 17: 93, page 382] }\end{array}$ \\
\hline
\end{tabular}

Analysis:

The word "Zukhruf" is modified with a comparison (like silver and pure gold). The modification has only one meaning component, that is RELATION (like silver and pure gold).

\section{A Loan Word with a Classifier}

In the translation of Islamic terms, loan words that contribute to the nearest meaning of Islamic terms are badly needed. Many translators use different ways in translating Islamic terms that probably need to be translated concretely based on the Qur'an and AsSunnah to avoid misunderstanding. Larson (1998:169) explained that: A loan word refers to a word which is from another language and is unknown to most the speakers of the receptor 
language. Loan words are commonly used for the names of people, places, geographical areas, etc. These words will often need to have a classifier added so that it is clear whether the word is the name of a person, town, country, river, or what. John could be translated a man named John. Once this was included, the name could be used without the claasifier later if the language structure indicated this as the best way to handle reference to participants.

Data Number 1

\begin{tabular}{|c|c|c|}
\hline No. & Arabic & English \\
\hline 1. & 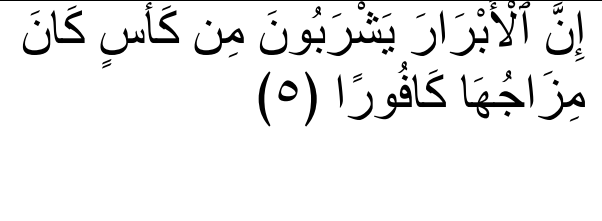 & $\begin{array}{l}\text { Verily,, the Abrar (the pious believers of } \\
\text { Islamic Monotheism), shall drink a cup } \\
\text { (of wine) mixed with (water from a } \\
\text { spring in Paradise called) Kafur. [Verse } \\
76: 5 \text {, page } 803 \text { ] }\end{array}$ \\
\hline
\end{tabular}

Analysis:

The word "Kafur" is modified with a classifier (water from a spring in Paradise). This classifier shows the name of a river in Paradise. Larson
(1998:169) explained that these words will often need to have a classifier added so that it is clear whether the word is the name of a person, town, country, river, or what.

\section{Data Number 6}

\begin{tabular}{|c|c|c|}
\hline No. & Arabic & English \\
\hline 1. & 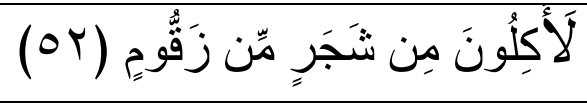 & $\begin{array}{l}\text { "You verily will eat of the trees of } \\
\text { Zaqqum. [Verse 56: 52, page 736] }\end{array}$ \\
\hline
\end{tabular}

Analysis:

The word "Zaqqum" is modified with a classifier (the trees of). This classifier shows the name of trees in Hell. Larson (1998:169) explained that these words will often need to have a classifier added so that it is clear whether the word is the name of a person, town, country, river, or what.

\section{A Loan Word with couplets, triplets, quadruplets and quintaplets}

In the translation of Islamic terms, loan words that contribute to the nearest meaning of Islamic terms are badly needed. Many translators use different ways in translating Islamic terms that probably need to be translated concretely based on the Qur'an and AsSunnah to avoid misunderstanding.
Newmark (1988:91) explained that: Couplets, triplets, quadruplets combine two, three or four of the above mentioned procedures recpectively for dealing with a single problem. They are particularly common for cultural words, if transference is combined with a functional or a cultural equivalent. You can describe them as two or more bites at one cherry. "It may be simply to emphasize the idea or to modify the area of meaning slightly" (Larson 1998:156).

In the Arabic language, there are many terms which consist of two or four meanings that are used to tell the vast meaning of them. That is why, the translator should be careful in choosing a suitable word to represent the meaning of one term. If needed, they must give footnotes (or references) just to make 
the meaning clear. Couplets, Triplets, needed to make up the translation. Quadruplets and Quintuplets are badly

\section{Couplets}

Data Number 1

\begin{tabular}{|c|c|c|}
\hline No. & Arabic & English \\
\hline 1. & 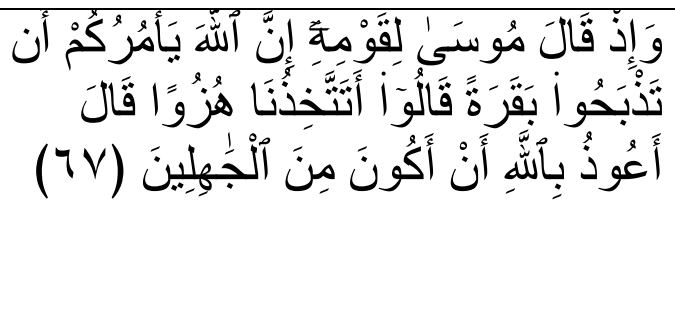 & $\begin{array}{l}\text { And (remember) when Musa (Moses) said } \\
\text { to his people: "Verily, Allâh commands } \\
\text { you that you slaughter a cow." They said, } \\
\text { "Do you make fun of us?" He said, "I take } \\
\text { Allâh's Refuge from being among Al- } \\
\text { Jahilun (the ignorant or the foolish)." } \\
\text { [Verse 2: 67, page 14] }\end{array}$ \\
\hline
\end{tabular}

Analysis:

The word "Al-Jahilun" is modified with couplets (the ignorant and the foolish). The word "Al-Jahilun" is extended by adding appositive phrase (the ignorant and the foolish) which gives more information to the readers. Larson (1998:91) explained that Couplets, triplets, quadruplets combine two, three, or four of the above mentioned procedures respectively for dealing with a single problem.

Triplets

Data Number 1

\begin{tabular}{|c|c|c|}
\hline No. & Arabic & English \\
\hline 1. &  & $\begin{array}{l}\text { Say: "Tell me! If this (Qur'an) is from } \\
\text { Allâh and you who deny it, and a withness } \\
\text { from among the Children of Israel } \\
\text { ("Abdullah bin Salam r) testifies that this } \\
\text { Qur'an is from Allâh like [the Taurat } \\
\text { (Torah)], and he believed (embraced } \\
\text { Islam) }{ }^{[1]} \text { while you are too proud to } \\
\text { (believe)." Verily, Allâh guides not the } \\
\text { people who are Zâlimun (polytheist, } \\
\text { disbelievers and wrongdoers). [Verse } \\
\text { 46: 10, page 682] }\end{array}$ \\
\hline
\end{tabular}

Analysis:

The word "Zalimun" is modified with triplets (polytheist, disbelievers and wrongdoers). The word "Zalimun" has so many meanings in the Arabic language, but these three are completely representative to the context. Larson (1998:91) explained that Couplets, triplets, quadruplets combine two, three, or four of the above mentioned procedures respectively for dealing with a single problem.

\section{Quadruplets}

Data Number 1

\begin{tabular}{|c|c|c|}
\hline No. & Arabic & English \\
\hline 1. &  & $\begin{array}{l}\text { And in the earth are neighbouring tracts, } \\
\text { and gardens of vines, and green corps } \\
\text { (fields), and date-palms, growing into two } \\
\text { or three from a single stem root, or }\end{array}$ \\
\hline
\end{tabular}






Analysis:

The word "Ayat" is modified with quadruplets (proofs, evidences, lessons, signs). Larson (1998:91) explained that
Couplets, triplets, quadruplets combine two, three, or four of the above mentioned procedures respectively for dealing with a single problem.

\section{Quintuplets}

Data Number 1

\begin{tabular}{|c|c|c|}
\hline No. & Arabic & English \\
\hline 1. & 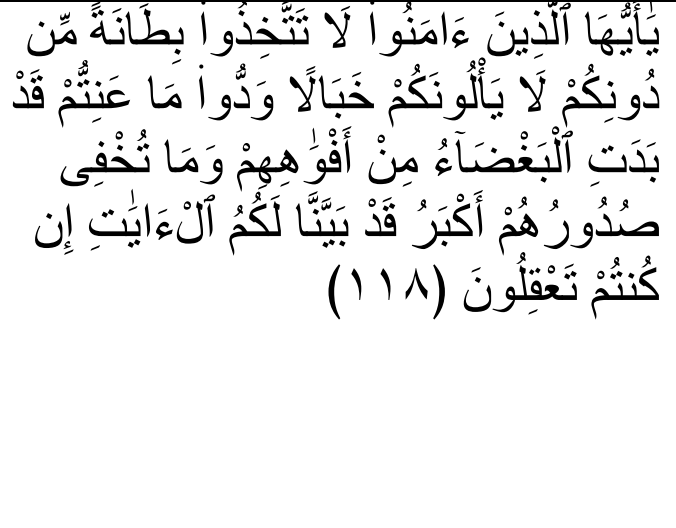 & $\begin{array}{l}\text { O you who believe! Take not as (your) } \\
\text { Bitanah (advisors, consultants, } \\
\text { protectors, helpers, friends) those } \\
\text { outside your religion (pagans, Jews, } \\
\text { Christians, and hypocrites) since they will } \\
\text { not fail to do their best to corrupt you. } \\
\text { They desire to harm you severely. Hatred } \\
\text { has already appeared from their mouths, } \\
\text { but what their breasts conceal is far worse. } \\
\text { Indeed We have made plain to you the } \\
\text { Ayat (proofs, evidences, verses) if you } \\
\text { understand. [Verse 3: 118, page } 90-91 \text { ] }\end{array}$ \\
\hline
\end{tabular}

Analysis:

The word "Bitanah" is modified with quadruplets (advisors, consultants, protectors, helpers, friends). Larson (1998:91) explained that Couplets, triplets, quadruplets combine two, three, or four of the above mentioned procedures respectively for dealing with a single problem.

\section{A Loan Word with a Synonym}

In the translation of Islamic terms, loan words that contribute to the nearest meaning of Islamic terms are badly needed. Many translators use different ways in translating Islamic terms that probably need to be translated concretely based on the Qur'an and AsSunnah to avoid misunderstanding.
Larson (1998:156) explained that: For example, English has a number of terms such as goodness, holiness, righteousness, and virtue, but Aguaruna has only one word, pegkeg, which would be the best equivalent for any one of these synonyms. On the other hand, if one were translating Aguaruna into English, one would need to evaluate each context of pegkeg to decide which of the synonyms would be the best choice in English. The choice will depend on the collocational range of each of the synonyms. Although there is overlap in the meaning of the synonyms, there may be well restrictions of collocation which will need be considered in choosing among the synonyms. 
Data Number 1

\begin{tabular}{|c|c|c|}
\hline No. & Arabic & English \\
\hline 1. &  & $\begin{array}{l}\text { He said: "O Adam! Inform them of } \\
\text { their names," and when he had } \\
\text { informed them of their names, He } \\
\text { said: "Did I not tell you that I know } \\
\text { the Ghaib (Unseen) in the heavens } \\
\text { and the earth, and I know what you } \\
\text { reveal and what you have been } \\
\text { concealing?" [Verse 2: 33, page 9] }\end{array}$ \\
\hline
\end{tabular}

Analysis:

The word "Ghaib" is modified with a synonym (Unseen). The word "Ghaib" has so many meanings but the synonym (Unseen) is the best collocational word in the context. Allah [Exalted be He] said: "O Adam! Tell the angels about the names of the things that I have displayed to them." When Adam told the angels about the names, Allah [Exalted be $\mathrm{He}$ ] said to the angels, admonishing: "I have told you that I know what have been concealed from you of the heavens and the earth. And I know, in addition to My knowledge of the unseen in the heavens and the earth, what you reveal by your tongues and that which you hide within your inner selves, so nothing can be concealed from Me. Ibn Katheer (may Allah have mercy upon him) said: "In this position Allah [Exalted be $\mathrm{He}$ ] has mentioned the preference and nobility of Adam over the angels as He favored him with the knowledge of the names of everything. This took place after the angels' Sujud (prostration) to Adam, but Allah has advanced this chapter to suit what came between the position of nobility of Adam and the angels' unawareness of the wisdom behind creating the kaleefah, when they asked about that, so Allah told them that $\mathrm{He}$ knows that which they do not know."

Data Number 3

\begin{tabular}{|c|c|c|}
\hline No. & Arabic & English \\
\hline 3. & 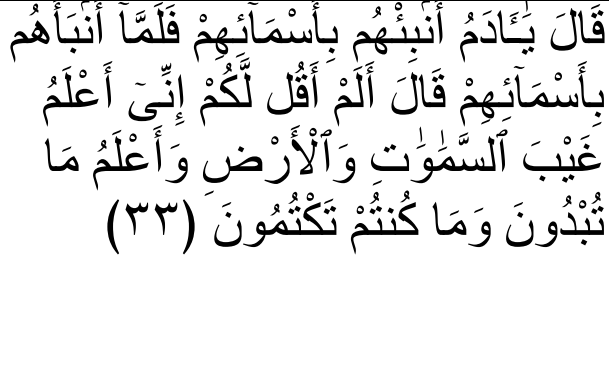 & $\begin{array}{l}\text { And We said: "O Adam! Dwell you } \\
\text { and your wife in the Paradise and eat } \\
\text { both of you freely with pleasure and } \\
\text { delight, of things therein as wherever } \\
\text { you will, but come not near this tree or } \\
\text { you both will be of the Zalimun } \\
\text { (wrong-doers)." [Verse 2: 35, page } \\
\text { 35] }\end{array}$ \\
\hline
\end{tabular}

Analysis:

The word "Zalimun" is modified with a synonym (Wrong-doers). The word "Zalimun" has so many meanings but the synonym (Wrong-doers) is the best collocational word in the context. "but come not near this tree or you both will be of the Zâlimûn (wrong-doers).": "this tree": Allah [Exalted be $\mathrm{He}$ ] pointed to a certain tree and $\mathrm{He}$ alone knows its type. However, the lack of this knowledge does not affect or harm us. "or you both will be of the Zâlimûn (wrong-doers).": i.e. if you eat from this tree you shall hurt yourself by committing the sin. 


\section{A Loan Word with a Synonym plus Reference}

This is an important technique in most translation, but not at all, except for the translation of the Noble Qur'an. To use this kind of technique, the translator must firstly explain the terms with the longest form of addition so that the readers have to recall their memories about the terms. The idea of omitting references is to have an equivalent translation. Sometimes it keep the readers' attention on one single ayah before they continue to the next ayah. Most readers read for specific information so that they always start reading the book in which the information is provided. Finally, the use of reference may not be neglected because it is better than just put a loan word plus synonym.

Data Number 1

\begin{tabular}{|c|c|c|}
\hline No. & Arabic & English \\
\hline 1. & 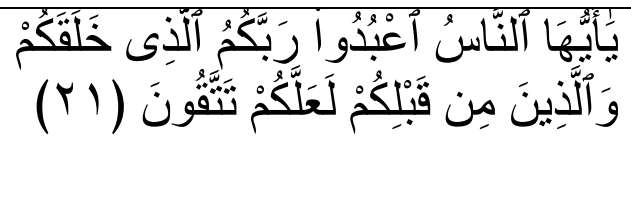 & $\begin{array}{l}\text { O mankind! Worship your Lord (Allah), } \\
\text { Who created you and those who were } \\
\text { before you so that you may become } A l \text { - } \\
\text { Muttaqun (the pious - See V.2:2). [Verse } \\
\text { 2: 22, page 6] }\end{array}$ \\
\hline
\end{tabular}

Analysis:

The word "Al-Muttaqun" is modified with a synonym (the pious) and a reference (See V.2:2). This strategy is to inform the readers to refer to the previous verses to find the meaning of the word "Al-Muttaqun."

Data Number 3

\begin{tabular}{|c|c|c|}
\hline No. & Arabic & English \\
\hline 3. & وَكَذَبَ بِالْلَحُسْنَىَ (9) & $\begin{array}{l}\text { And belies Al-Husna (See the footnote of } \\
\text { the Verse No. 6). [Verse 92: 9, page } 839 \text { ] }\end{array}$ \\
\hline
\end{tabular}

Analysis:

The word "Al-Husna" is modified with a reference (See the footnote of the Verse No. 6). This word has been mentioned before in the Surah, the verse no.6, so the readers could go back a few verses to know the meaning of it.

\section{A Loan Word with no Modification}

This method of translation is also important for eficiency, it can be applied when the term has been mentioned previously or there is a footnote as a reference. This way is to keep the readers not go further with their own interpretation.

Data Number 1

\begin{tabular}{|c|c|c|}
\hline No. & Arabic & English \\
\hline 1. &  & $\begin{array}{l}\text { And perform As-Salat (Iqamat-as- } \\
\text { Salat), and give Zakat, and bow down } \\
\text { (or submit yourselves with obedience } \\
\text { to Allah) along with Ar-Rakiun }{ }^{[2]} \text {. } \\
\text { [Verse 2: 43, page 10] }\end{array}$ \\
\hline
\end{tabular}


Analysis:

The word "Ar-Rakiun" has no modification but there is a footnote that the readers could look at the detail meaning. The word "Ar-Rakiun" means all Muslim should pray five times a day in congregation in the mosque. The Hadiths state that the threat of punishment for one who does not come to prayer is that his prayer will not be accepted, such as the Hadith which says: "Whoever heard the call (to prayer) and did not answer it, there is no prayer for him, unless he has an excuse (i.e. due to illness or travel)" (Ibn Majah no. 793, Ad-Daraqutni 1: 420 and AlHakim 1: 245).

Data Number 3

\begin{tabular}{|c|c|c|}
\hline No. & Arabic & English \\
\hline 3. & 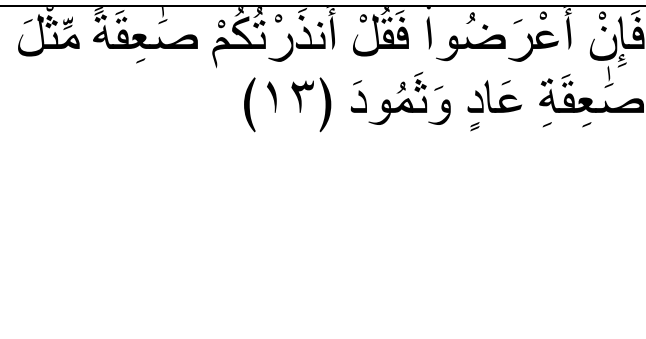 & $\begin{array}{l}\text { But if they turn away, then say (O } \\
\text { Muhammad صليه وسلم): "I have } \\
\text { warned you of a Sa'iqah (a destructive } \\
\text { awful cry, torment, hit, a thunderbolt) } \\
\text { like the Sa'iqah which overtook 'Ad } \\
\text { and Thamud (people)." [Verse 41: 13, } \\
\text { page 644] }\end{array}$ \\
\hline
\end{tabular}

Analysis:

The word "Sa'iqah" does not need to be modified because it is already mentioned before. The word "Sa'iqah" is a great torment for Ad and Thamud because of their arrogance. They believed that their strong houses will protect them from Allah's Torment (the very cold wind).

Table 1. The Number and Percentage of the Translation Procedures

\begin{tabular}{|c|l|c|c|}
\hline No. & Translation Procedures & Total & Percent \\
\hline 1. & A loan word with features of form & 15 & $13 \%$ \\
\hline 2. & A loan word with function & 2 & $2 \%$ \\
\hline 3. & A loan word with both form and function & 29 & $26 \%$ \\
\hline 4. & A loan word with a comparison & 6 & $5 \%$ \\
\hline 5. & A loan word with a classifier & 8 & $7 \%$ \\
\hline 6. & A loan word with couplets, triplets, quadruplets and & 31 & $27 \%$ \\
& quintuplets & 11 & $10 \%$ \\
\hline 7. & A loan word with synonym & 5 & $4 \%$ \\
\hline 8. & A loan word with synonym plus reference & 6 & $5 \%$ \\
\hline 9. & A loan word with no modification & & \\
\hline
\end{tabular}




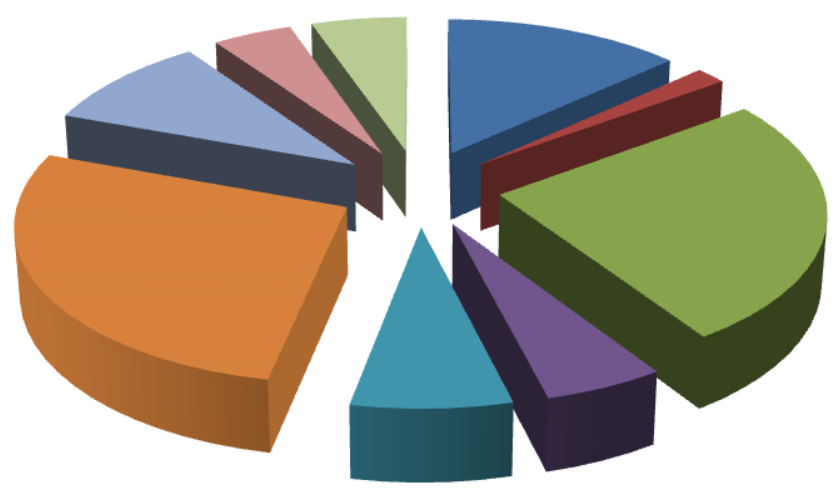

A loan word with features
of form
A loan word with function
A loan word with both
form and function
A loan word with a
comparison
A loan word with a
classifier
A loan word with couplets,
triplets, quadruplets and
quintuplets
A loan word with synonym

Diagram 1. Translation using a loan word in the Nobel Qur'an

\section{CONCLUSION}

Based on the research there are nine general strategies of translating a loan word in the Noble Qur'an. First, a loan word with features of form; second, a loan word with function; third, a loan word with form and function; fourth, a loan word with comparison; fifth, a loan word with classifier; sixth, a loan word with couplets, triplets, quadruplets and quintaplets; seventh, a loan word with synonym; eigth, a loan word with synonym, ninth, a loan word with sysonym plus reference. The strategy of translation, named a loan word with couplets, triplets, quadruplets and quintaplets, is frequently employed by professional translators because there are so many repetitional words in the Noble Qur'an. This strategy is to give a complete understanding about a term that has multiperception but this once more limits the multiperception by giving two or more definitions in every single word.

\section{REFERENCES}

Al-Hilali, M. T., \& Muhammad, M. K. (1418 AH). The Noble Qur'an: English Translation of the Meanings and Commentary. King Fahd Complex for the Printing of the Holy Qur'an: Madinah Munawwarah, K.S.A.

Baker, M. (2002). In Other Words: A Course Book on Translation. USA and Canada: Routledge.

Cambridge Advanced Learner's Dictionary. (2008). Third Edition. Singapore: Cambridge University Press.

Haywood, J. A., \& H M Nahmad. (2005). A New Arabic Grammar of the Written Language. London: Lund Humpries Publisher Ltd.

Larson, M. L. (2004). Meaning-Based Translation. Lanham: University Press of America.

Lester, J. D., James, D., \& Lester Jr. (2003). Principles of Writing Research Papers: Pearson Education, Inc.

Longman Dictionary of English Language and Culture. (2002). Essex: Longman Group UK Limited.

Stevens, A. M., \& A Ed. SchmidgallTellings. (2008). A Comprehensive Indonesian-English Dictionary. Jakarta: Mizan Media Utama. 